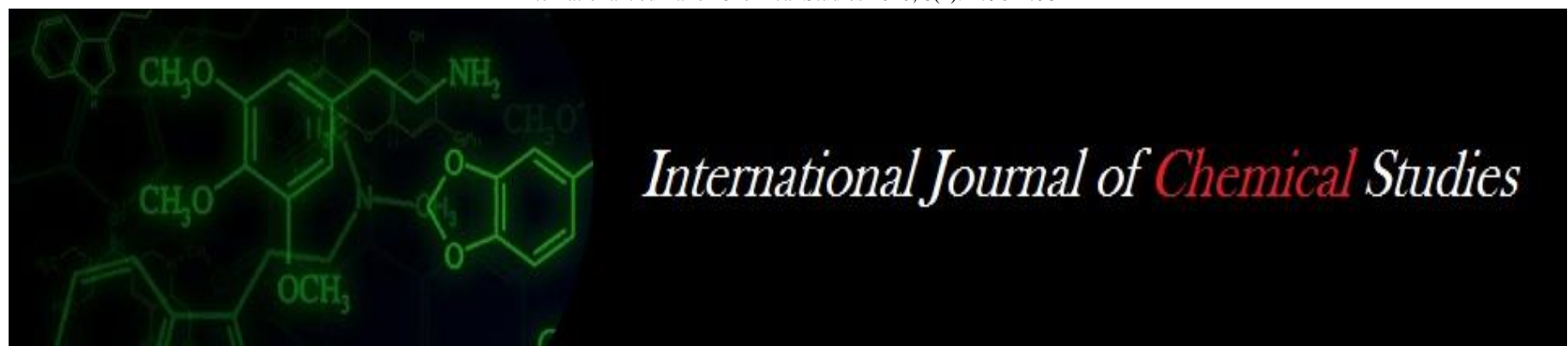

P-ISSN: 2349-8528

E-ISSN: 2321-4902

www.chemijournal.com

IJCS 2020; 8(4): 2790-2795

(C) 2020 IJCS

Received: 10-05-2020

Accepted: 12-06-2020

Bilal Ahmad Beigh

Department of Environmental

Science and Limnology,

Barkatullah University,

Madhya Pradesh, India

Ashwani Wanganeo

Department of Environmental

Science and Limnology,

Barkatullah University,

Madhya Pradesh. India

Ashok Kumar Pandit

Aquatic Ecology Laboratory,

Centre of Research for

Development (CORD),

University of Kashmir,

Jammu and Kashmir, India

Rajni Wanganeo

Department of Zoology, Govt.

Benazir Science and Commerce

College, Madhya Pradesh, India

Corresponding Author: Bilal Ahmad Beigh

Department of Environmental

Science and Limnology,

Barkatullah University,

Madhya Pradesh, India

\section{Assessment of seasonal variation in physico- chemical characteristics of a lentic waterbody of Bhopal, India}

\author{
Bilal Ahmad Beigh, Ashwani Wanganeo, Ashok Kumar Pandit and Rajni \\ Wanganeo
}

DOI: https://doi.org/10.22271/chemi.2020.v8.i4ag.10066

\begin{abstract}
The present study was conducted with an aim to assess the seasonal variation and nutrient status of a lentic water body (Lower lake) of Bhopal, India. Different variables involving water temperature (W.T), Secchi transparency (TRN), pH, total dissolved solids (TDS), conductivity (CON), total alkalinity (T.A), dissolved oxygen (DO), chlorides (CL), total hardness $(\mathrm{TH})$, orthophosphate $\left(\mathrm{PO}_{4}{ }^{-3}\right)$ and nitrate $\left(\mathrm{NO}_{3}-\mathrm{N}\right)$ were examined using the standard methodology of APHA (2005). Significant seasonal variation was observed in Secchi transparency which ranged from $27 \mathrm{~cm}$ to $83 \mathrm{~cm}$, chlorides $(29 \mathrm{mg} / \mathrm{l}$ to $58 \mathrm{mg} / \mathrm{l}$, dissolved oxygen $(1.6 \mathrm{mg} / \mathrm{l}$ to $9.2 \mathrm{mg} / \mathrm{l})$, phosphate $(1.76 \mathrm{mg} / \mathrm{l}$ to $2.9 \mathrm{mg} / \mathrm{l})$ and nitrate $(0.98 \mathrm{mg} / \mathrm{l}$ to 3.57 $\mathrm{mg} / \mathrm{l})$. Our results confer that the water body is undergoing nutrient enrichment especially littoral sites due to direct influx of untreated sewage from surrounding urban settlements which has resulted in the deterioration of water quality of the lake. Pearson correlation analysis was employed to determine the relationship among water parameters which revealed both significant positive and negative trends.
\end{abstract}

Keywords: Lentic water body, seasonal variation, nutrient status

\section{Introduction}

Fresh water bodies occupy relatively small portion of the earth surface as compared to marine habitats, but their importance to man is far greater than marine systems due to direct dependence on these habitats. Lakes and reservoirs have been called the ecological barometers of the health of a city as they play a role in the regulation of the microclimate of any urban area (Ateshan and Saxena, 2015) ${ }^{[4]}$. The quality of water of the surface water bodies have a profound effect on urban ground water recharging network due to existence of direct interaction between surface and groundwater (Jumbe et al., 2008; Ravikumar et al., 2013) ${ }^{[8,}$ ${ }^{24]}$. Lakes provide range of environmental services, such as (a) drinking and irrigation water (b) support livelihoods- provide food and nutrition (c) recharge aquifers (d) recreational servicesboating, swimming and fishing (e) rain waters harvesting (f) temporarily store storm water to prevent floods ( $\mathrm{g}$ ) wildlife habitat for fishes and birds and, (h) emergency water supply for fire fighting. Ecologically managed lakes are considered as natural infrastructures to climate change mitigation and adaptation strategy.

Today surface water bodies are most exposed to pollution due to its easy accessibility for disposal of pollutants and wastewaters. During the last decade, widespread deterioration in water quality of aquatic systems has been reported due to extensive use of synthetic fertilizers in agriculture, rapid development of industries and urban sprawl (Olajire and Imeokparia, 2001; Murray et al., 2010) ${ }^{[19,18]}$. The water quality and the health of the aquatic ecosystem of lakes are very sensitive issues and are essentially determined through its trophic status; based on a classification scale for how productive the lake is. Eutrophication is an ecological process, similar to aging, in which a water body is increasingly enriched. The dynamic nature of the biological productivity and eutrophication due to natural and enhanced anthropogenic activities leaves no single assessment variable as a true measure of the nutrient status of a

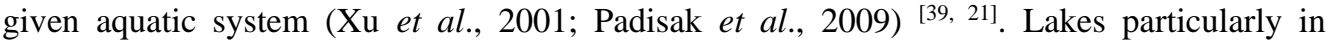
developing countries are unfortunately facing severe problems due to varied human activities and unsustainable use of these resources. Human activities in the surrounding watershed have been accelerating the process of nutrient enrichment thereby affecting the water quality, 
resulting in loss of biodiversity and ecological functions. In India, lakes and reservoirs are experiencing varying degrees of environmental degradation due to encroachments, eutrophication (from domestic and industrial effluents) and siltation. Development has brought many undesirable modifications to environment with increased number of industries and population. There has been a tremendous population increase during the last century without a corresponding expansion of civic facilities, resulting in lakes and reservoirs, especially urban ones, becoming contaminant sinks. Sustainable supply of fresh and clean water to growing population is one of the main issues of populated cities like Bhopal.

\section{Study area}

Lower lake $\left(23^{\circ} 16^{\prime} 0^{\prime \prime} \mathrm{N}\right.$ and $\left.77^{\circ} 25^{\prime} 0^{\prime \prime} \mathrm{E}\right)$ is an urban waterbody located in the heart of Bhopal city of Madhya Pradesh (Fig. 1 ). The city is famous for its numerous lakes. Lower lake is a part of Bhoj wetland (a Ramsar site) which comprises two man-made basins, the "Upper lake" and the "Lower lake".
The Lower lake has been constructed on the downstream of the dam of Upper lake. The lake receives subsurface seepage from the Upper Lake and drainage from numerous sewage filled nallahs. The waterbody has area of $1.29 \mathrm{~km}^{2}$ and catchment area of $9.6 \mathrm{~km}^{2}$. The average depth of the waterbody appeared to be $3.8 \mathrm{~m}$ with maximum depth of 10.7 $\mathrm{m}$. Lower lake is surrounded on all sides by dense urban settlements. The waterbody faces anthropogenic degradation mainly due to human population growth and urbanization.

In the present investigation, 4 sampling sites, 3 littoral sites viz., Site I (Kali Mandir), Site II (Ginnori) and Site III (MVM College) and a central site (Site IV) have been selected to represent catchment characteristics and ecological conditions prevailing in the lake (Fig.). Submerged and floating macrophytes such as Ceratophyllum demersum, Hydrilla verticillata and Eichornia crassipes grow in the lake. Among all the sites, Site IV is the deepest site located towards the centre of the lake and is devoid of any macrophytic vegetation.
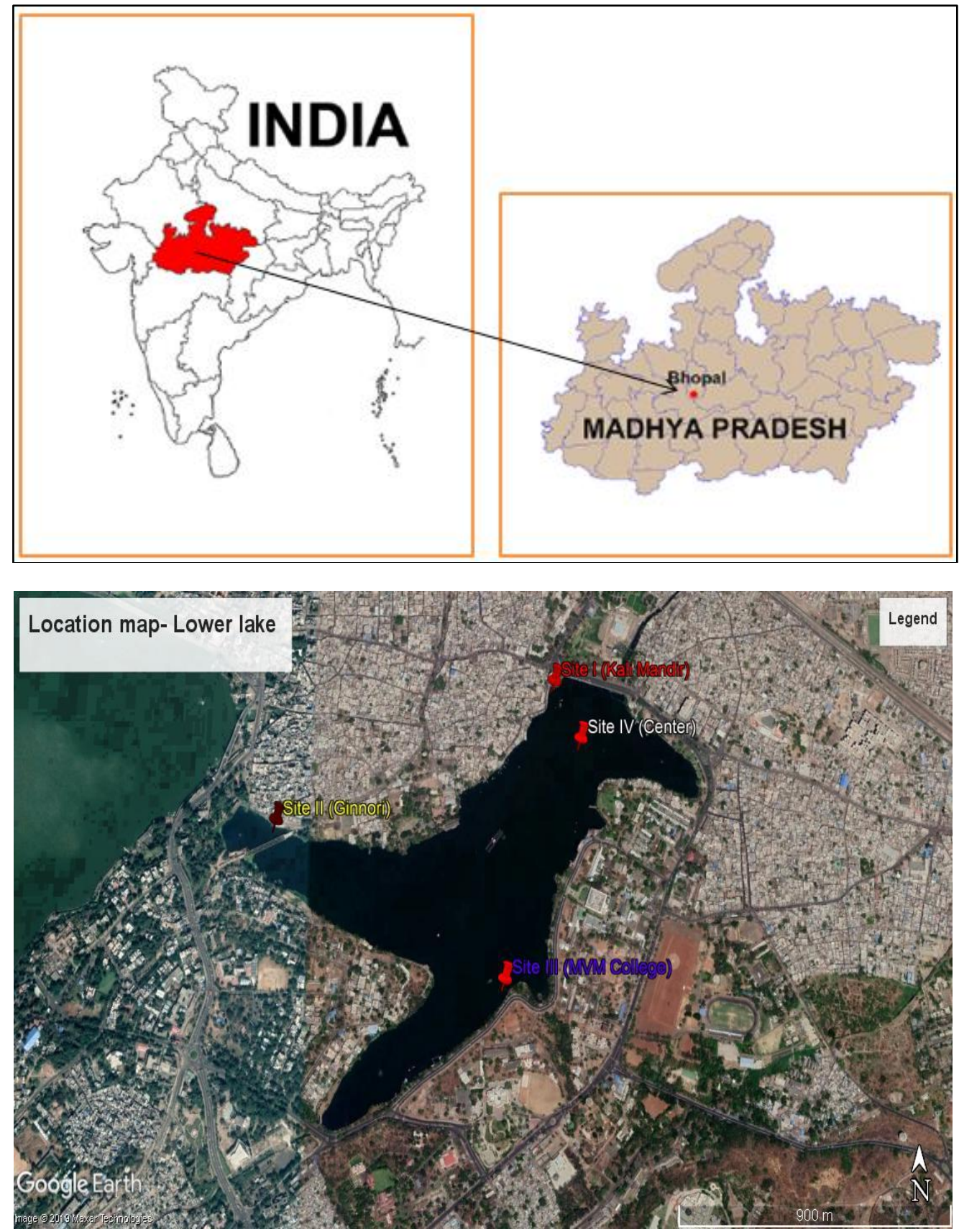

Fig 1: Lower lake of Bhopal 


\section{Material and Methods}

Water samples were collected in triplicates from selected sites during winter, 2016 to monsoon, 2016 and the results were expressed as average values. Collected water samples were preserved and transported to laboratory and analysed within 24 hour as per the standard procedures recommended by APHA (2005) ${ }^{[2]}$ and CSIR (1974). Water temperature and $\mathrm{pH}$ were measured on the spot by means of a mercury thermometer and digital $\mathrm{pH}$ meter. Dissolved oxygen (DO) was analysed by modified Winkler method (APHA 1998). The other selected water quality parameters include total alkalinity, chlorides, total hardness, nitrate-nitrogen and orthophosphorus $\left(\mathrm{PO}_{4}{ }^{3-}\right)$. Careful calibration and blank measurements were performed to acquire accurate values (APHA 2005; CSIR 1974) ${ }^{[2]}$. Statistical analysis was carried out using OPSTAT (Sheoran et al., 1998) ${ }^{[29] .}$

\section{Result and Discussion}

Lower lake is located within the tropical conditions, atmospheric temperature ranged between $20.4{ }^{\circ} \mathrm{C}$ in winter and $39^{\circ} \mathrm{C}$ in summer (Fig. 2a). Water temperature is regarded as vital, as it controls distribution of aquatic biota (Wetzel, 1983) [36], influences limnological phenomenon such as solubility of gases, $\mathrm{pH}$, conductivity and biological production (Singh, 1990; Lewis, 2000) ${ }^{[12]}$. In the present study, the water temperature showed significant seasonal variation (ranged from $16.7{ }^{\circ} \mathrm{C}$ to $29{ }^{\circ} \mathrm{C}$ ) in winter and summer respectively (Fig. 2b). The Secchi transparency fluctuated between $27 \mathrm{~cm}$ to $83 \mathrm{~cm}$ as depicted in Fig. 2c. Lowest transparency in summer season is a consequence of suspended matter and maximum population of phytoplankton (Microcystis aeruginosa, Scenedesmus sp. and Planktothrix aghardhii) in the epilimnetic water which significantly reduce the penetration of light into the lake. In contrast, maximum water transparency during winter may be attributed to low phytoplankton population, low suspended load due to absence of rains and run-off. This fact is in agreement with the studies of Mahar, (2003) ${ }^{[15]}$ and Singh et al., (2017) ${ }^{[33]} . \mathrm{pH}$ is an important hydrological variable as it influences many biological and chemical processes within a water body (Shah and Pandit, 2013; Yaseen et. al., 2015) ${ }^{[26]}$. The $\mathrm{pH}$ of the lake water fluctuated between 6.8 units during winter to 8.9 units in summer (Fig. 2d). Near neutral pH has also been observed by Wanganeo and Ishaq, (2011) [34] and Ahmad and Wanganeo, (2015) [6] in Bhoj wetland of Bhopal. Furthermore, alkaline nature of the water reveals productive nature of the waterbody. Whitemore, (1989) [37] and Whitemore et al., (2006) ${ }^{[38]}$ described alkaline $\mathrm{pH}$ to be a characteristic feature of eutrophic and mesotrophic waters. The concentration of TDS varied between $286 \mathrm{ppm}$ at Site IV in winter to $460 \mathrm{ppm}$ at Site II during monsoon implying that TDS concentration in the lake is also controlled by rainfall during which urban run-off loaded with silt and clay in combination with influx of household sewage result in the increasing concentration of dissolved solids. Salahuddin et al., (2013) ${ }^{[25]}$ also related high TDS load to entry of urban wash off and sewage into the Narsinh Mehta Lake of Gujrat during rainy season. Similarly, conductivity which gives an indication about the total ionic strength of the solution varied from $372 \mu \mathrm{S} \mathrm{cm}^{-1}$ (at Site IV) to $537 \mu \mathrm{S} \mathrm{cm}$ at Site II in summer and monsoon season respectively (Fig. 2f). Higher values of conductivity during monsoon season reflects the influx of sewage from surrounding human habitations and subsequent mineralization of organic matter thereby causing an increase in the conductivity of water as also opined by
Prasannakumari et al., (2000) ${ }^{[23]}$, Khatri and Dhankar, (2003) [10] and Sharma and Tiwari, (2018). The low conductivity values recorded during summer season may be due to maximum uptake of nutrients by the autotrophs (Lu et al., 2010; Bhat and Pandit, 2014) ${ }^{[5]}$. Wanganeo and Pani, (1998) ${ }^{[35]}$ have reported low average conductivity values for Lower lake $\left(255.71 \mu \mathrm{S} \mathrm{cm}^{-1}\right)$ as compared to our studies indicating that the waterbody has considerably accumulated nutrients during the course of time. According to Kadam, (1990) [9], waterbodies having high electrical conductivity indicate higher pollution status. Alkalinity is a quantitative capacity of water to neutralize acids. The lake water was found to be alkaline $(126 \mathrm{mg} / \mathrm{l}$ in summer to $174 \mathrm{mg} / \mathrm{l}$ in winter) throughout the monitoring period (Fig. $2 \mathrm{~g}$ ). Similar trend has been obtained by Bhat et al., (2015) ${ }^{[6]}$ in Bhoj wetland of Bhopal. The concentration of chloride in Lower lake was quite high and fluctuated between $29 \mathrm{mg} / \mathrm{l}$ in winter and 58 $\mathrm{mg} / \mathrm{l}$ in summer (Fig. 2h). Lower lake receives organic waste and untreated sewage continuously from adjacent housing colonies which is responsible for the rise in chloride levels as

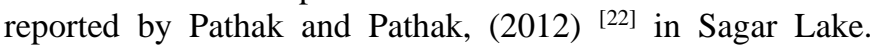
Dissolved oxygen (DO) is one of the most important parameter, helps in determining the water quality criteria of a water body. Its concentration is essential to support the biodiversity of aquatic ecosystems (Parna and Burrows, 2005; Matta et al., 2015). Minimum dissolved oxygen $(1.6 \mathrm{mg} / \mathrm{l})$ at Site III and maximum dissolved oxygen $(9.2 \mathrm{mg} / \mathrm{l})$ at Site IV was recorded during monsoon and summer season respectively (Fig. 2i). The high concentration of DO in lake water during summers is a consequence of high planktonic production due to which more oxygen is released as a result of photosynthetic activity. Authors like Singhal et al., (1986) and Sharma, (2014) also reported high DO concentration during summer months in different waterbodies of India. Total hardness values varied between $120 \mathrm{mg} / \mathrm{l}$ to $162 \mathrm{mg} / \mathrm{l}$ with high concentration in monsoon and low in winter season (Fig. 2j). The runoff loaded with high concentration of $\mathrm{Ca}$ and $\mathrm{Mg}$ cations in addition to sulphates and nitrate during monsoon rains may be the reason for higher hardness in lake during monsoon season. Besides this, Lower lake is situated in the heart of the densely populated city, so there is continuous influx of sewage into the lake, thereby altering the water quality of the lake. High hardness values during monsoon season have been reported by Angadi et al., (2005) [3] in Papnash pond of Karnataka. Phosphorus (P) is a key biological nutrient required for all living organisms. Biological organisms commonly take orthophosphate $\left(\mathrm{PO}_{4}{ }^{3-}\right)$ which is a soluble form of phosphorus. The concentration of this critical nutrient ranged from $1.76 \mathrm{mg} / \mathrm{l}$ in summer to 2.9 $\mathrm{mg} / \mathrm{l}$ in monsoon season (Fig. 2k). Lower value during summer indicates its incorporation in algal biomass which has also been confirmed by Komárková and Hejzlar, (1996) in Rimov reservoir of Czech. However, high concentration of orthophosphate during monsoon may be related to the contribution of runoff from surrounding areas due to which substantial amount of phosphate is washed down into the lake. Ling et al., (2017) [13] also confirmed rise in phosphate concentration in a tropical reservoir of Malaysia during rainy season. Furthermore, the values of orthophosphate obtained in our study were extremely high in comparison to previous records of Valecha et al., (1991) who recorded $\mathrm{PO}_{4}{ }^{3-}$ in the range of $0.095 \mathrm{mg} / \mathrm{l}$ to $0.42 \mathrm{mg} / \mathrm{l}$ indicating that the waterbody is undergoing tremendous nutrient enrichment resulting in increased algal biomass and deterioration of water quality of the lake. The concentration of $\mathrm{NO}_{3}-\mathrm{N}$ in the waterbody 
fluctuated between $0.98 \mathrm{mg} / \mathrm{l}$ in summer and $3.57 \mathrm{mg} / \mathrm{l}$ in winter (Fig. 1). The contribution of nitrate in urban water bodies is mainly due to discharge of nitrogenous wastes. Decrease in nitrate level in summer may be due to three processes which include its uptake by phytoplankton as a source of nutrient, its reduction to ammonical form and incorporation in biomass (Maier, 2015). Gosh and Salla, (2014) reported enhancement in nitrate concentration to the extent of $2.81 \mathrm{mg} / \mathrm{l}$ in Lower lake and concluded that the main contribution of this nutrient is household sewage and organic matter.
Pearson Correlation analysis was employed to determine the relationship among the physico-chemical variables (Table 1). $\mathrm{pH}$ showed significant positive correlation with water temperature $\left(\mathrm{r}=0.967^{*}, p<0.05\right)$, whereas significant negative correlation existed between total alkalinity and water temperature $\left(\mathrm{r}=-0.994^{*}, \quad p<0.05\right)$. Chlorides depicted significant negative correlation with transparency $\left(\mathrm{r}=-0.999^{*}\right.$, $p<0.05)$ and total alkalinity $\left(\mathrm{r}=-0.998^{*}, p<0.05\right) . \mathrm{PO}_{4}{ }^{3-}$ revealed significant negative correlation with $\mathrm{pH}\left(\mathrm{r}=-0.994^{*}\right.$, $p<0.05)$. Significant negative correlation was observed between $\mathrm{NO}_{3}-\mathrm{N}$ and water temperature $\left(\mathrm{r}=-0.993^{*}, p<0.05\right)$.

Table 1: Pearson correlation between physico-chemical parameters

\begin{tabular}{|c|c|c|c|c|c|c|c|c|c|c|}
\hline & W.T & TRN & pH & TDS & CON & T. A & CL & DO & TH & PO $_{4}{ }^{3-}$ \\
\hline TRN & -0.977 & & & & & & & & & \\
\hline pH & $0.967^{*}$ & -0.892 & & & & & & & & \\
\hline TDS & 0.761 & -0.881 & 0.572 & & & & & & & \\
\hline $\mathrm{CON}$ & -0.461 & 0.263 & -0.67 & 0.225 & & & & & & \\
\hline T. A & $-0.994^{*}$ & 0.994 & -0.935 & -0.826 & 0.363 & & & & & \\
\hline CL & 0.987 & $-0.999^{*}$ & 0.913 & 0.857 & -0.309 & $-0.998^{*}$ & & & & \\
\hline DO & 0.736 & -0.576 & 0.883 & 0.121 & -0.94 & -0.659 & 0.615 & & & \\
\hline TH & -0.23 & 0.02 & -0.469 & 0.456 & 0.97 & 0.125 & -0.068 & -0.828 & & \\
\hline $\mathrm{PO}_{4}{ }^{3-}$ & -0.932 & 0.835 & $-0.994^{*}$ & -0.475 & 0.751 & 0.888 & -0.861 & -0.931 & 0.567 & \\
\hline $\mathrm{NO}_{3-\mathrm{N}}$ & $-0.993^{*}$ & 0.972 & -0.973 & -0.745 & 0.482 & 0.991 & -0.982 & -0.752 & 0.254 & 0.941 \\
\hline
\end{tabular}

* Correlation is significant at the 0.05 level
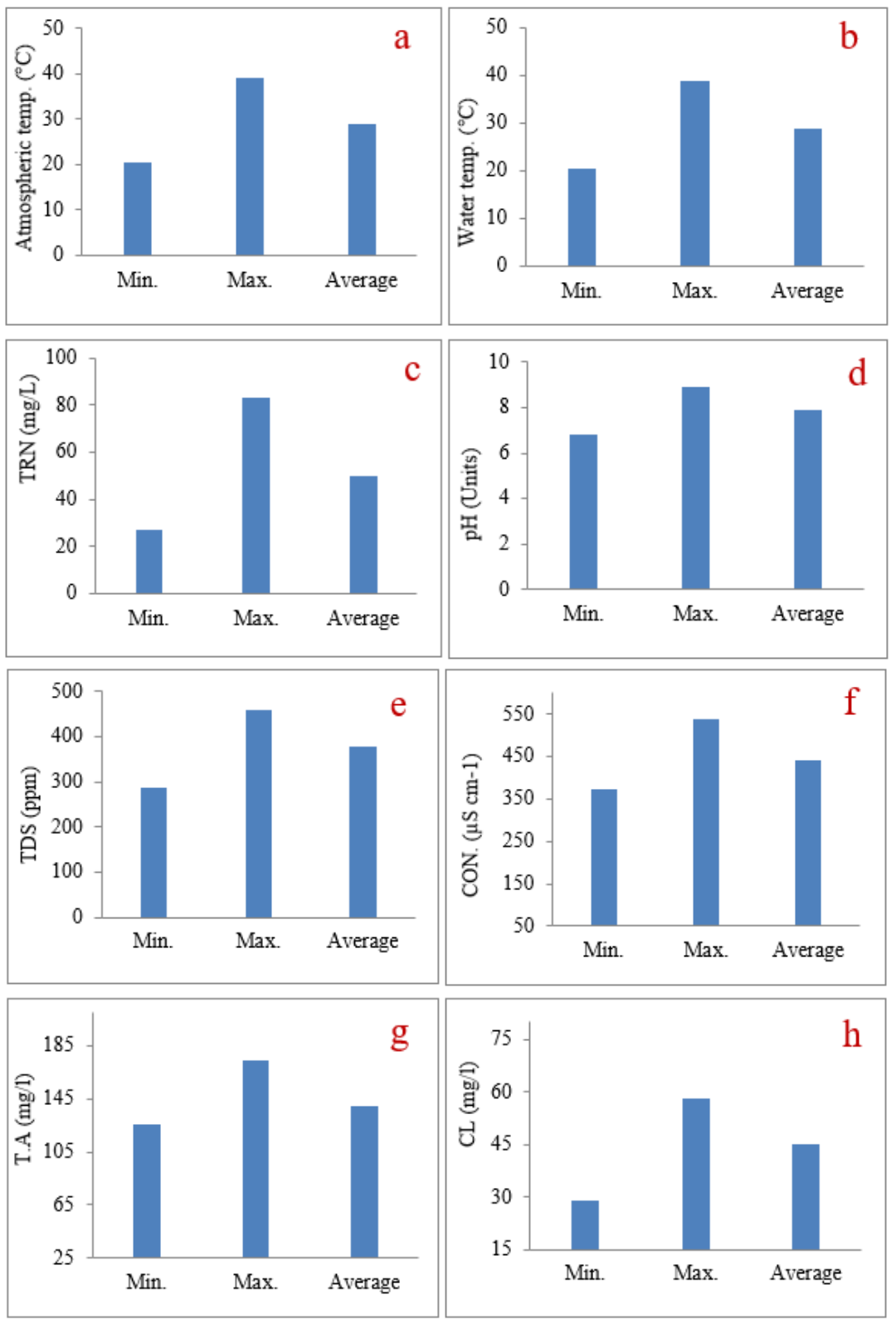

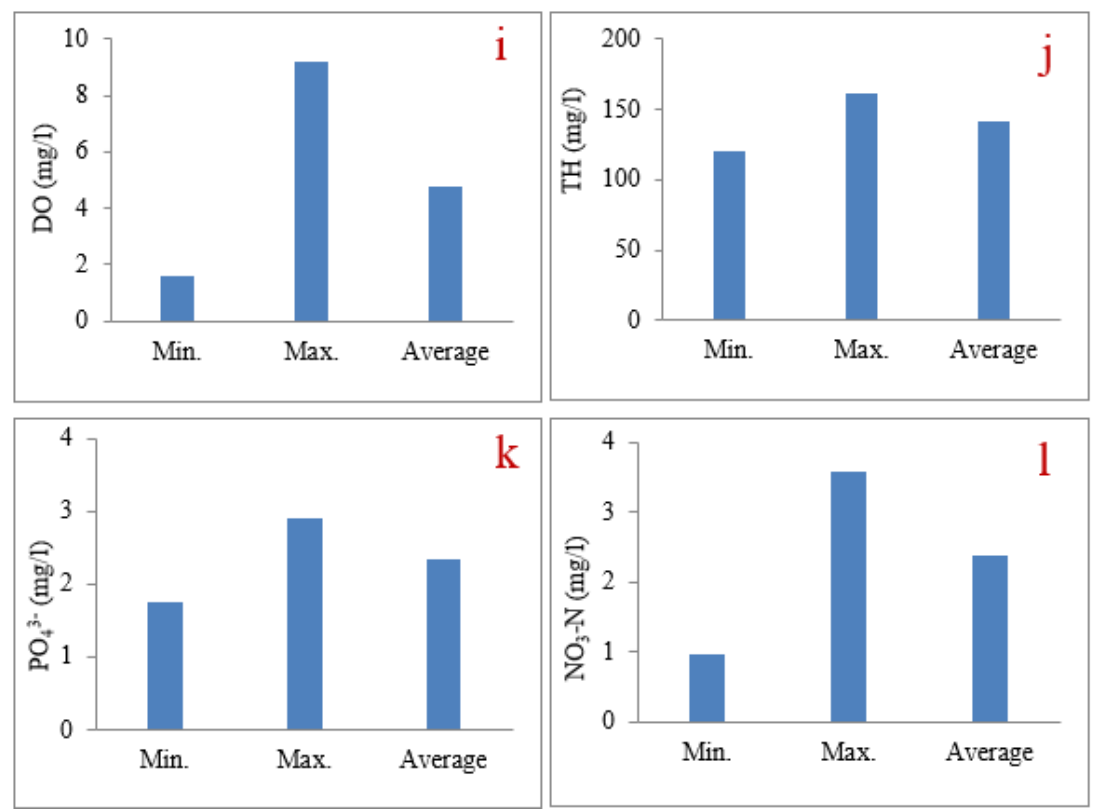

Fig (2a- 1): Variation in various limnological variables of Lower lake

\section{Conclusion}

The present study revealed that Lower lake is experiencing increasing disturbances from anthropogenic activities occurring in the vicinity like input of untreated domestic sewage and storm water runoff mainly responsible for the nutrient enrichment in the lake. High values of orthophosphate, nitrate and low Secchi transparency reflect high nutrient status of the waterbody. Sewage treatment management and solid waste management are suggested to prevent the waterbody from deterioration and destruction.

\section{References}

1. Ahmad A, Wanganeo A. Phytoplankton succession in a tropical freshwater lake, Bhoj wetland, (Bhopal, India): spatial and temporal perspective. Environmental Monitoring and Assessment, 2015, 187-192.

2. American Public Health Association (APHA). Standard method for examination of water and wastewater, 21st edn. APHA, AWWA, WPCF, Washington, 2005.

3. Angadi SB, Shiddamaliayya N, Patil PC. Limnological study of papnash pond, Bidar (Karnataka). Journal of Environmental Biology. 2005; 26:213-216.

4. Ateshan HM, Saxena PR. Assessment of PhysicoChemical Parameters of Kattamaisamma Lake of Sooraram Village, Hyderabad, Telangana State, India. International Journal of Advanced Research in Science and Technology. 2015; 4(4):437-440.

5. Bhat SA, Pandit AK. Surface water quality assessment of Wular Lake, A Ramsar site in Kashmir Himalaya, using discriminant analysis and WQI. Journal of Ecosystem. 2014; 724-728:1-18.

6. Bhat NA, Wanganeo A, Raina R. Seasonal dynamics of phytoplankton community in a tropical wetland. Environmental Monitoring and Assessment, 2015; 187:4136.

7. Ghosh S, Salla S. Limnological studies of lower lake of Bhopal, India. International Journal of Mathematics and Physical Sciences Research. 2014; 1(1):30-37.

8. Jumbe AS, Nandini N, Tandon S, Sunitha N. Bangalore lakes-issues and perspectives on pollution, restoration and management. Proceedings of Taal 2007: The 12th world lake conference, 2008, 1699-1706.
9. Kadam SD. Environmental study of lake Rankala, Jaynati Nala and Lake Kotitirth from Kolhapur city. Environment and Ecology. 1990; 8(1):95-97.

10. Khatri SK, Dhankar R. Evaluation of sewage waste water as a source of irrigation and manure of Rohtak city of Haryana. Pollution Research. 2003; 22(4):549-552.

11. Komárková J, Hejzlar J. Summer maxima of phytoplankton in the Rímov Reservoir in relation to hydrologic parameters and phosphorus loading. Archiv fur Hydrobiologie. 1996; 136(2):217-236.

12. Lewis WM. Basis for the protection and management of tropical lakes. Lakes and Reservoirs: Resource and Management. 2000; 5(1):35-48.

13. Ling T, Gerunsin N, Soo C, Nyanti N, Sim S, Grinang J. Seasonal changes and spatial variation in water quality of a large Young Tropical Reservoir and its downstream river. Journal of Chemistry, Article ID 8153246, 2017, 16.

14. Lu Q, He ZL, Graetz DA, Stoffella PJ, Yang X. Phytoremediation to remove nutrients and improve eutrophic storm waters using water lettuce (Pistia stratiotes L.). Environmental Science and Pollution Research. 2010; 17(1):84-96.

15. Mahar MA. Ecology and taxonomy of plankton of Manchhar lake, Sindh, Pakistan. Ph.D thesis, University of Sindh, Pakistan, 2003.

16. Maier RM. Biogeochemical Cycling. Environmental Microbiology, 2015, 339-373.

17. Matta G, Srivastava S, Pandey RR, Saini KK. Assessment of physicochemical characteristics of Ganga Canal water quality in Uttarakhand. Environment, Development and Sustainability. 2015; 19(2):419-431.

18. Murray KE, Thomas SM, Bodour AA. Prioritizing research for trace pollutants and emerging contaminants in the freshwater environment. Environmental Pollution. 2010; 158(12):3462-3471.

19. Olajire AA, Imeokparia FE. Water quality assessment of Osun river: studies on inorganic nutrients. Environmental Monitoring and Assessment. 2001; 69(1):17-28.

20. Otsuki A, Wetzel GR. Co-precipitation of phosphate with carbonate in a marl lake. Limnology and Oceanography. 1974; 17:763-776. 
21. Padisak J, Crossetti LO, Naselli-Flores L. Use and misuse in the application of the phytoplankton functional classification: a critical review with updates. Hydrobiologia. 2009; 621:1-19.

22. Pathak H, Pathak D. Eutrophication: impact of excess nutrient status in lake water ecosystem. Journal of Environment and Toxicology. 2012; 2:148.

23. Prasannakumari AA, Arathy MS, Ganga Devi T. Biogeo- chemical studies of a temple pond with special reference to macroflora. Pollution Research. 2000; 19(4):623-631

24. Ravikumar P, Mehmood AM, Somashekar RK. Water quality index to determine the surface water quality of Sankey tank and Mallathahalli lake, Bangalore urban district, Karnataka, India. Applied Water Science. 2013; 3:247-261.

25. Salahuddin K, Virendra S, Manish V, Chirag G, Zofair SM. Limnological studies of Junagadh District in Gujarat, India. International Research Journal of Environment Sciences. 2013; 2(5):9-16.

26. Shah JA, Pandit AK. Relationship between physicochemical limnology and Crustacean community in Wular lake of Kashmir Himalaya. Pakistan Journal of Biological Sciences. 2013; 16(19):976-983.

27. Sharma M. Water quality assessment of the Central Himalayan Lake, Nainital. Advances in Environmental Chemistry, Article ID 473074, 2014, 5.

28. Sharma RC, Tiwari V. Seasonal physico-chemical characterization of water of sacred lake Nachiketa Tal, Garhwal Himalaya. Applied Water Science. 2018; 8:164.

29. Sheoran OP, Tonk DS, Kaushik LS, Hasija RC, Pannu RS. Statistical Software Package for Agricultural Research Workers. Recent Advances in information theory, Statistics \& Computer Applications by D.S. Hooda \& R.C. Hasija Department of Mathematics Statistics, CCS HAU, Hisar, 1998, 139-143.

30. Singhal RN, Swaranjeet, Davies RW. The physicochemical environment and the plankton of managed ponds in Haryana, India. Proceedings of the Indian Academy of Science. 1986; 95(3):353-363.

31. Singh AK, Kumari R, Singh DK. Assessment of water quality using physico-chemical parameters in two flood plain lakes (Chaurs), North Bihar, India. International Research Journal of Environmental Sciences. 2017; 6(9):26-37.

32. Valecha V, Valecha R, Bhatnagar GP. Limnology of a sewage polluted lake: the Lower lake (Bhopal, India). Internationale Revue der gesamten Hydrobiologie. 1991; 76(1):137-147.

33. Murray KE, Thomas SM, Bodour AA. Prioritizing research for trace pollutants and emerging contaminants in the freshwater environment. Environmental Pollution. 2010; 158(12):3462-3471.

34. Wanganeo A, Ishaq A. Post de weeding and dredging changes in some limnological characteristics of upper basin of Bhoj wetland. Current Biotica. 2011; 5(3):299311.

35. Wanganeo A, Pani S. Impact of nutrient influx on water quality trends of a Vindhyan lake during a decade, In: Advances in Fish and Wildlife Ecology and Biology, II, Ed. Kaul, B.K., 1998, 119-136.

36. Wetzel RG. Limnology, 2nd ed., Philadelphia: Saunders College Publishing, U.S.A, 1983.
37. Whitemore TJ. Florida diatom assemblages as indicators of trophic state and $\mathrm{pH}$. Limnology and Oceanography. 1989; 34:882-895.

38. Whitemore TJ, Brenner M, Kolasa KV, Kenney WF, Riedinger-Whitmore MA, Curtis JH et al. Inadvertent alkalization of a Florida Lake caused by increased ionic and nutrient loading to its watershed. Journal of Paleolimnology. 2006; 36:353-370.

39. Xu FL, Tao S, Dawson RW, Li BG. A GIS-based method of lake eutrophication assessment. Ecological Modelling. 2001; 144(2, 3):231-244.

40. Yaseen S, Pandit AK, Shah JA. Water quality index of fresh water streams feeding Wular Lake, in Kashmir Himalaya, India. International Journal of Water Resources and Environmental Engineering. 2015; 7(4):50-57. 